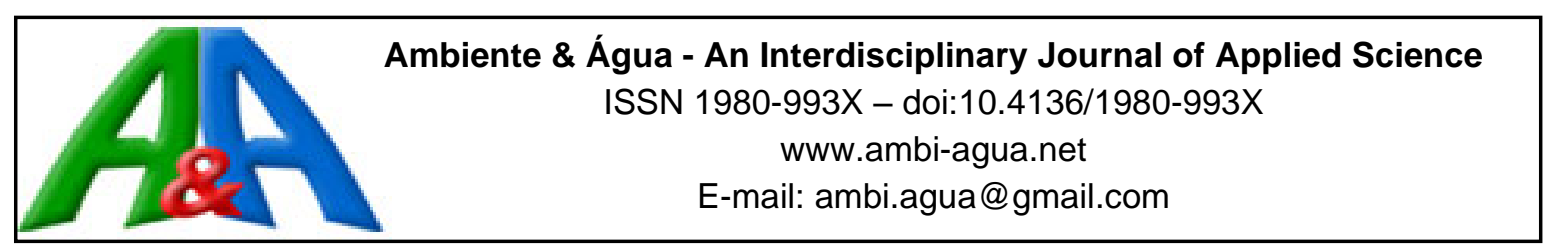

\title{
Drinking water quality indices: a systematic review
}

\author{
ARTICLES doi:10.4136/ambi-agua.2630
}

Received: 03 Aug. 2020; Accepted: 26 Feb. 2021

\begin{abstract}
Rodrigo Augusto Klamt ${ }^{1}$; ; Adilson Ben da Costa ${ }^{2}$; Mari Ângela Gaedke ${ }^{3}$; Eduardo Alexis Lobo ${ }^{2 *}$

${ }^{1}$ Programa de Pós-graduação em Tecnologia Ambiental. Universidade de Santa Cruz do Sul (UNISC), Avenida Independência, $\mathrm{n}^{\circ}$ 2293, CEP: 96816-501, Santa Cruz do Sul, RS, Brazil. E-mail: rodrigoklamt@ hotmail.com ${ }^{2}$ Departamento de Ciências da Vida. Universidade de Santa Cruz do Sul (UNISC), Avenida Independência, n² 2293, CEP: 96816-501, Santa Cruz do Sul, RS, Brazil. E-mail: adilson@ unisc.br

${ }^{3}$ Departamento de Ciências da Saúde. Universidade de Santa Cruz do Sul (UNISC), Avenida Independência, n 2293, CEP: 96816-501, Santa Cruz do Sul, RS, Brazil. E-mail: marig@unisc.br

*Corresponding author. E-mail: lobo@unisc.br
\end{abstract}

\begin{abstract}
This analysis applied systematic review as a methodology for identifying, analyzing and interpreting data on the use of water quality indices for human consumption. Scientific articles were searched in the "PubMed", "Scielo", "ScienceDirect" and "Web of Science" databases, using the keywords "drinking water" and "water quality index", with a custom interval between 2000 and 2020. The results indicated 82,573 published articles, with 16 of them being selected after a filtering process. The occurrence of 11 water quality indices was verified, including 47 water quality parameters used to assess the quality of drinking water, highlighting that the parameters $\mathrm{pH}$, Nitrate, Turbidity, Chloride and Sulfate were the most used, cited in 10 of the 16 articles selected $(62,5 \%)$. We suggest that future studies seek to propose regionalized water quality indicators for consumption, in order to consider local aspects in the evaluation process and to determine intervention priorities by health surveillance agencies.
\end{abstract}

Keywords: drinking water, systematic review, water quality indices.

\section{Índice de qualidade de água para consumo humano: uma revisão sistemática}

\section{RESUMO}

Esta análise aplica a revisão sistemática como metodologia para identificar, analisar e interpretar dados sobre o uso de índices de qualidade da água para consumo humano. Os artigos científicos foram pesquisados nas bases de dados "PubMed", "Scielo", "Science Direct" e "Web of Science", usando as palavras-chave "água potável" e "índice de qualidade da água", com um intervalo personalizado entre 2000 e 2020. Os resultados indicaram 82573 artigos publicados, sendo 16 deles selecionados após um processo de filtragem. Verificou-se a ocorrência de 11 índices de qualidade da água, incluindo 47 parâmetros de qualidade da água utilizados para avaliar a qualidade da água potável, destacando que os parâmetros $\mathrm{pH}$, nitrato, turbidez, cloreto e sulfato foram os mais utilizados, citados em 10 dos 16 artigos selecionados $(62,5 \%)$. Sugerimos que pesquisas futuras procurem propor indicadores regionalizados de qualidade da água para consumo, a fim de considerar aspectos locais no processo de avaliação e determinar prioridades de intervenção por órgãos de vigilância em saúde.

Palavras-chave: água potável, índices de qualidade da água, revisão sistemática. 


\section{INTRODUCTION}

Sustainable access to drinking water is essential for human life, health and well-being. However, surface water bodies that are the most important water sources for human activities are, unfortunately, under severe environmental stress, being threatened because of anthropogenic activities (Yogendra and Puttaiah, 2008). Thus, poor water quality in rural communities causes health inequality, especially in developing countries. The quality of drinking water can be controlled through a combination of water source protection, treatment process control and water management. The guidelines must be appropriate for regional and local circumstances, which requires adaptation to environmental issues, social, economic and cultural circumstances, and setting priorities (WHO, 2006).

Several physical, chemical and biological parameters are used to characterize water quality, which can be integrated in a Water Quality Index (WQI) to describe, for instance, the degree to which a waterbody is suitable for consumption purposes (Tyagi et al., 2013). A WQI provides a single number that expresses overall water quality based on importance weights assigned to each water quality parameter. WQI's are widely used as a practical method for representing pollution problems in water bodies. They do not require a huge number of different water quality parameters for development and validation, only the concentration of a limited number of parameters (Akkoyunlu and Akiner, 2012). Water resource specialists generally determine the water quality state and its trends, based on the assessment of individual water quality parameters. While professionals readily understand this technical language, nontechnical people have difficulty in understanding these water quality results (Cude, 2001).

One of the most widespread indices in the world is the National Sanitation Foundation Water Quality Index (NSF WQI) developed by Brown et al. (1970) for the United States. The NSF WQI was established by selecting nine variables: dissolved oxygen, fecal coliforms, $\mathrm{pH}$, biochemical oxygen demand (BOD), temperature, total phosphate and nitrate concentrations, turbidity, and total solid content. Five classes for water quality were defined: red (very poor), orange (poor), yellow (average), green (good) and blue (excellent) (Kachroud et al., 2019). The NSF WQI was developed to compare the quality of water bodies and monitor temporal or spatial changes in water quality, mainly applied to pollution from domestic sewage and eutrophication processes (Finotti et al., 2015; Klamt et al., 2019). The WQI can also indicate the contribution of industrial effluents, as long as they are of a biodegradable organic nature (CETESB, 2019). The NSF WQI was calibrated for subtropical and temperate Brazilian lotic systems by Moretto et al. (2012), based on Resolution 357/2015 from the Brazilian National Environment Council (CONAMA, 2005). The calculations were made using the IQAData software (Posselt et al., 2015).

The potability standards in Brazil are established in Consolidation Ordinance No. 5/2017 (Brasil, 2017), which provides the procedures for the control and surveillance of water quality and potability standards for human consumption, as well as establishing the competences and responsibilities assigned to public health authorities. The Annex XX of this Consolidation Ordinance shows the physical-chemical and bacteriological parameters for consumption, highlighting the Free Residual Chlorine, pH, Apparent Color, Fluoride, Turbidity, Total Coliforms, Escherichia coli and Heterotrophic Bacteria as standards of potability. Changes in their physical-chemical and microbiological properties can compromise their quality, enabling the creation of environments favorable to the development of vectors, which can alter and/or suppress ecosystems and biomes, in addition to causing the emergence and aggravation of population's health problems.

According to Chapter II, Art. $5^{\circ}$, Section II of this Consolidation Ordinance, drinking water is defined as the water that meets the potability standard established in Annex XX, not offering health risks (BRASIL, 2017). On the other hand, according to the National Health Foundation 
(FUNASA), water for human consumption must not contain pathogenic microorganisms and be free of bacteria from coliform group, which are indicators of fecal contamination, being represented mainly by Escherichia coli (FUNASA, 2009).

Currently, there is a lack of WQI's for drinking purposes, especially those focused on simpler parameters, at low cost, generating qualitative information accessible to the population. In this context, this study uses the systematic review methodology developed by Petersen $e t$ al. (2008), aimed at identifying, analyzing and interpreting data on the use of WQI's for human consumption, trying to find the most relevant publications, the possible research gaps, and their challenges, but mainly to identify the main parameters used and the composition of WQI's.

\section{METHODOLOGY}

This study is characterized as a systematic review, defined by the use of data from the literature, seeking to integrate information from a set of studies carried out separately on a given topic, which may present conflicting or coincident results (Sampaio, 2007). A scientific article that applies the systematic review as a methodology aims to identify, analyze and interpret all available evidence related to a specific research question (Kitchenham and Charters, 2007), in this case addressed to the use of WQI's for human consumption. This type of methodology discusses not only the conclusion, but also all activities related to the main theme. Thus, a systematic study collects data on the places where the activity occurs and the media in which it was published. The methodology consists of elaborating the research questions, designing the research process and defining the criteria for filtering the results (Cooper, 2016).

\subsection{Research questions}

The review covers articles published from January 2000 until March 2020, over a period of 20 years. The first general question (GQ1) is to identify which WQI's were applied to classify water quality (Table 1). From this, a specific question (FQ1) and a statistical question (SQ1) were defined.

Table 1. Research questions.

\begin{tabular}{ll}
\hline Reference & Questions \\
\hline General question (GQ1) & Which indices were applied to classify the quality of drinking water? \\
Specific question (FQ1) & Which variables were found in the research? \\
Statistic question (SQ1) & Where were the surveys published? \\
\hline
\end{tabular}

\subsection{Research process}

According to Petersen et al. (2008), three stages are defined during the research process: (1) Specify the research keywords, (2) Choose the databases to apply the research keywords, and (3) Get the results. The first step begins by identifying the main terms and their most relevant synonyms. Thus, scientific articles were searched using the keywords "drinking water" and "water quality index", in the PubMed, Scielo, ScienceDirect and Web of Science databases, with a custom interval between 2000 and 2020 .

\subsection{Applying filters}

In order to filter the most relevant scientific information, the following criteria (C) were included:

C1. The study must be published in a scientific magazine or newspaper. 
C2. The study must be directly related to WQI's for consumption.

C3. The study must be a complete work.

C4. Keywords must be included in the title.

The selected articles were stored in EndNote $X 7^{\circledR}$ software (Thomson Reuters), where the texts were organized in specific folders for each research database. The next filter was based on the three-step approach introduced by Srinivasan Keshav (2007). The first step was a quick scan and consists of reading the title, summary and introduction. In the second step, only the section and subsection headings are read. Finally, in the third step, the mathematical content (if any) is examined to determine the underlying theoretical foundations.

\section{RESULTS AND DISCUSSION}

Table 2 shows the filtering process, with criteria $\mathrm{C} 1$ to $\mathrm{C} 4$ applied in each stage. Based on the results obtained, the articles were organized by title, year of publication, authors, databases, technologies and work objectives.

Table 2. Filtering process.

\begin{tabular}{cccccc}
\hline Database & Initial search & Keywords in the title & $\mathbf{C 1}$ & $\mathbf{C 2}$ & $\mathbf{C 3 / C 4}$ \\
\hline PubMed & 126 & 32 & 24 & 24 & $3(2,38 \%)$ \\
Scielo & 38 & 1 & 1 & 1 & $0(0 \%)$ \\
Science Direct & 42815 & 356 & 356 & 344 & $10(0,02 \%)$ \\
Web of science & 39594 & 26 & 15 & 15 & $3(0,01 \%)$ \\
Total & 82573 & 415 & 396 & 381 & $16(0,02 \%)$ \\
\hline
\end{tabular}

\subsection{GQ1 - Which indices were applied to classify water quality?}

A WQI is a tool to present a numerical expression derived cumulatively to define a certain level of water quality. In other words, a WQI summarizes large amounts of water quality data in simple terms (for example, excellent, good and bad) to report to management authorities and non-technical people consistently. The WQI concept is based on the comparison of water quality parameters with their respective regulatory standards, and gives a unique value to water quality, which translates the list of constituents and their concentrations present in a sample. The formulation and use of indices have been strongly advocated by agencies responsible for water supply and water pollution control. Table 3 shows the WQIs for consumption that have been used.

In some studies, more than one WQI was used, being modified for consumption purposes, and several citations followed the standards of the World Health Organization, which deals with drinking water guidelines. The Indian Standard Bureau (ISB) is an institution that regulates and provides details on the permitted and desirable standard specifications and limits of various parameters in drinking water. The CCME Water Quality Index, based on a formula developed by the British Columbia Ministry of Environment, is a quality index that summarizes complex data on water quality to facilitate its communication to the public. The NSF index was developed to provide a standardized method for comparing the water quality of various bodies. 
Table 3. Water quality indices used and respective references.

\begin{tabular}{|c|c|}
\hline Water Quality Indices & Articles \\
\hline Bhargava Water Quality Index. & Avvannavar and Shrihari (2008). \\
\hline $\begin{array}{l}\text { GWQI - Groundwater Quality } \\
\text { Index. }\end{array}$ & Masocha et al. (2019). \\
\hline $\begin{array}{l}\text { National Sanitation Foundation } \\
\text { Index (NSF). }\end{array}$ & Gharibi et al. (2012); Barakat et al. (2018); Cooray et al. (2019). \\
\hline WQI CCME. & $\begin{array}{l}\text { Gharibi et al. (2012); Hurley et al. (2012); Mohebbi et al. (2013); Abtahi } \\
\text { et al. (2015). }\end{array}$ \\
\hline Water Quality Index (WQI). & Batabyal and Chakraborty (2015). \\
\hline $\begin{array}{l}\text { Drinking Water Quality Index } \\
\text { (DWQI). }\end{array}$ & $\begin{array}{l}\text { Scheili et al. (2015); Jasmin and Mallikarjuna (2014); Ramesh et al. } \\
\text { (2010); Ponsadailakshmi et al. (2018). }\end{array}$ \\
\hline $\begin{array}{l}\text { Fuzzy-based Water Quality } \\
\text { Index. }\end{array}$ & Gharibi et al. (2012). \\
\hline $\begin{array}{l}\text { Additive Water Quality Index } \\
\text { (AWQI). }\end{array}$ & Paca et al. (2019). \\
\hline $\begin{array}{l}\text { Multiplicative Water Quality } \\
\text { Index (MWQI). }\end{array}$ & Paca et al. (2019). \\
\hline $\begin{array}{l}\text { Scottish Water Quality Index } \\
\text { (SDD). }\end{array}$ & Bordalo and Savva-Bordalo (2007). \\
\hline $\begin{array}{l}\text { Integrated Water Quality Index } \\
\text { (IWQI). }\end{array}$ & Mukate et al. (2019). \\
\hline
\end{tabular}

\subsection{FQ1 - Which variables were found in the research?}

The researchers explored each index as a performance measure that aggregates information, reflecting the influence of physical, chemical and biological variables of water quality conditions. These are based on quality parameters with their respective regulatory standards, presenting a single value for water quality. Table 4 shows the parameters used and their respective references.

Table 4. Parameters used to assess the quality of drinking water and respective references.

\begin{tabular}{|c|c|}
\hline $\begin{array}{l}\text { Parameters } \\
\left(\mathbf{N}^{0} \text { of citations }\right)\end{array}$ & Articles \\
\hline $\mathrm{pH}(16)$ & $\begin{array}{l}\text { Paca et al. (2019); Batabyal and Chakraborty (2015); Scheili et al. (2015); Jasmin and } \\
\text { Mallikarjuna (2014); Cooray et al. (2019); Avvannavar and Shrihari (2008); Bordalo } \\
\text { and Savva-Bordalo (2007); Ramesh et al. (2010); Gharibi et al. (2012); Hurley et al. } \\
\text { (2012); Mohebbi et al. (2013); Abtahi et al. (2015); Barakat et al. (2018); } \\
\text { Ponsadailakshmi et al. (2018); Masocha et al. (2019); Mukate et al. (2019). }\end{array}$ \\
\hline Nitrate (13) & $\begin{array}{l}\text { Paca et al. (2019); Batabyal and Chakraborty (2015); Jasmin and Mallikarjuna } \\
\text { (2014); Bordalo and Savva-Bordalo (2007); Ramesh et al. (2010); Gharibi et al. } \\
\text { (2012); Hurley et al. (2012); Mohebbi et al. (2013); Abtahi et al. (2015); Barakat et } \\
\text { al. (2018); Ponsadailakshmi et al. (2018); Masocha et al. (2019); Mukate et al. } \\
\text { (2019). }\end{array}$ \\
\hline Turbidity (11) & $\begin{array}{l}\text { Paca et al. (2019); Batabyal and Chakraborty (2015); Scheili et al. (2015); } \\
\text { Avvannavar and Shrihari (2008); Bordalo and Savva-Bordalo (2007); Gharibi et al. } \\
\text { (2012); Hurley et al. (2012); Mohebbi et al. (2013); Abtahi et al. (2015); Barakat et } \\
\text { al. (2018); Masocha et al. (2019). }\end{array}$ \\
\hline
\end{tabular}

Continue... 
Continued..

Chlorides (10)

Batabyal and Chakraborty (2015); Jasmin and Mallikarjuna (2014); Cooray et al. (2019); Ramesh et al. (2010); Gharibi et al. (2012); Mohebbi et al. (2013); Abtahi et al. (2015); Barakat et al. (2018); Ponsadailakshmi et al. (2018); Mukate et al. (2019).

Sulfate (10)

Batabyal and Chakraborty (2015); Jasmin and Mallikarjuna (2014); Cooray et al.

(2019).

; Ponsadailakshmi et al. (2018); Masocha et al. (2019); Mukate et al.

Batabyal and Chakraborty (2015); Jasmin and Mallikarjuna (2014); Cooray et al.

Total hardness (9) (2019); Ramesh et al. (2010); Mohebbi et al. (2013); Abtahi et al. (2015); Barakat et al. (2018); Ponsadailakshmi et al. (2018); Masocha et al. (2019).

\begin{tabular}{ll}
\hline & Batabyal and Chakraborty (2015); Cooray et al. (2019); Bordalo and Savva-Bordalo \\
Iron (9) & al. (2007); Ramesh et al. (2010); Hurley et al. (2012); Mohebbi et al. (2013); Abtahi et \\
&
\end{tabular}
al. (2015); Ponsadailakshmi et al. (2018); Masocha et al. (2019).

Calcium (9)

Batabyal and Chakraborty (2015); Jasmin and Mallikarjuna (2014); Ramesh et al. Ponsadailakshmi et al. (2018); Masocha et al. (2019); Mukate et al. (2019).

Magnesium (8)

Batabyal and Chakraborty (2015); Jasmin and Mallikarjuna (2014); Ramesh et al. (2010); Mohebbi et al. (2013); Abtahi et al. (2015); Ponsadailakshmi et al. (2018); Masocha et al. (2019); Mukate et al. (2019).

Sodium (8)

Batabyal and Chakraborty (2015); Jasmin and Mallikarjuna (2014); Ramesh et al. (2010); Mohebbi et al. (2013); Abtahi et al. (2015); Ponsadailakshmi et al. (2018); Masocha et al. (2019); Mukate et al. (2019).

Fluorides (8)

Batabyal and Chakraborty (2015); Jasmin and Mallikarjuna (2014); Cooray et al. (2019); Ramesh et al. (2010); Gharibi et al. (2012); Mohebbi et al. (2013); Abtahi et al. (2015); Ponsadailakshmi et al. (2018).

Electric conductivity (8)

Paca et al. (2019); Batabyal and Chakraborty (2015); Cooray et al. (2019); Bordalo and Savva-Bordalo (2007); Ramesh et al. (2010); Barakat et al. (2018); Ponsadailakshmi et al. (2018); Masocha et al. (2019).

Total coliforms (7)

Avvannavar and Shrihari (2008); Ramesh et al. (2010); Gharibi et al. (2012); Hurley et al. (2012); Barakat et al. (2018); Masocha et al. (2019); Bordalo and SavvaBordalo (2007).

\begin{tabular}{|c|c|}
\hline Total dissolved solids (6) & $\begin{array}{l}\text { Batabyal and Chakraborty (2015); Jasmin and Mallikarjuna (2014); Gharibi et al. } \\
\text { (2012); Mohebbi et al. (2013); Abtahi et al. (2015); Mukate et al. (2019). }\end{array}$ \\
\hline Chrome (6) & $\begin{array}{l}\text { Bordalo and Savva-Bordalo (2007); Ramesh et al. (2010); Gharibi et al. (2012); } \\
\text { Mohebbi et al. (2013); Abtahi et al. (2015); Ponsadailakshmi et al. (2018). }\end{array}$ \\
\hline Nitrite (6) & $\begin{array}{l}\text { Bordalo and Savva-Bordalo (2007); Ramesh et al. (2010); Gharibi et al. (2012); } \\
\text { Mohebbi et al. (2013); Abtahi et al. (2015); Barakat et al. (2018). }\end{array}$ \\
\hline Total alkalinity (5) & $\begin{array}{l}\text { Batabyal and Chakraborty (2015); Cooray et al. (2019); Ramesh et al. (2010); } \\
\text { Barakat et al. (2018); Ponsadailakshmi et al. (2018). }\end{array}$ \\
\hline Manganese (5) & $\begin{array}{l}\text { Batabya and Chakraborty (2015); Ramesh et al. (2010); Mohebbi et al. (2013); } \\
\text { Abtahi et al. (2015); Ponsadailakshmi et al. (2018). }\end{array}$ \\
\hline Zinc (5) & $\begin{array}{l}\text { Batabyal and Chakraborty (2015); Ramesh et al. (2010); Mohebbi et al. (2013); } \\
\text { Abtahi et al. (2015); Ponsadailakshmi et al. (2018). }\end{array}$ \\
\hline Copper (5) & $\begin{array}{l}\text { Bordalo and Savva-Bordalo (2007); Ramesh et al. (2010); Mohebbi et al. (2013); } \\
\text { Abtahi et al. (2015); Ponsadailakshmi et al. (2018). }\end{array}$ \\
\hline Ammonia (5) & $\begin{array}{l}\text { Paca et al. (2019); Bordalo and Savva-Bordalo (2007); Mohebbi et al. (2013); } \\
\text { Abtahi et al. (2015); Barakat et al. (2018). }\end{array}$ \\
\hline
\end{tabular}

Continue... 


\begin{tabular}{|c|c|}
\hline \multicolumn{2}{|l|}{ Continued... } \\
\hline Potassium (4) & $\begin{array}{l}\text { Batabyal and Chakraborty (2015); Jasmin and Mallikarjuna (2014); Masocha et al. } \\
\text { (2019); Mukate et al. (2019). }\end{array}$ \\
\hline Lead (4) & $\begin{array}{l}\text { Ramesh et al. (2010); Gharibi et al. (2012); Mohebbi et al. (2013); Ponsadailakshmi } \\
\text { et al. (2018). }\end{array}$ \\
\hline Dissolved oxygen (4) & $\begin{array}{l}\text { Paca et al. (2019); Bordalo and Savva-Bordalo (2007); Gharibi et al. (2012); } \\
\text { Barakat et al. (2018). }\end{array}$ \\
\hline Arsenic (4) & $\begin{array}{l}\text { Bordalo and Savva-Bordalo (2007); Gharibi et al. (2012); Mohebbi et al. (2013); } \\
\text { Abtahi et al. (2015). }\end{array}$ \\
\hline Temperature (4) & $\begin{array}{l}\text { Scheili et al. (2015); Bordalo and Savva-Bordalo (2007); Gharibi et al. (2012); } \\
\text { Barakat et al. (2018). }\end{array}$ \\
\hline Escherichia coli (3) & Hurley et al. (2012); Abtahi et al. (2015); Barakat et al. (2018). \\
\hline Fecal coliforms (3) & Paca et al. (2019); Bordalo and Savva-Bordalo (2007); Mohebbi et al. (2013). \\
\hline $\begin{array}{l}\text { Biochemical oxygen } \\
\text { demand (3) }\end{array}$ & Paca et al. (2019); Avvannavar and Shrihari (2008); Gharibi et al. (2012). \\
\hline Total organic carbon (3) & Scheili et al. (2015); Hurley et al. (2012); Cooray et al. (2019). \\
\hline Cadmium (3) & Ramesh et al. (2010); Mohebbi et al. (2013); Gharibi et al. (2012). \\
\hline Aluminium (2) & Mohebbi et al. (2013); Abtahi et al. (2015). \\
\hline Phosphate (2) & Paca et al. (2019); Gharibi et al. (2012). \\
\hline Mercury (2) & Gharibi et al. (2012); Mohebbi et al. (2013). \\
\hline Fecal enterococci (2) & Bordalo and Savva-Bordalo (2007); Barakat et al. (2018). \\
\hline Bicarbonate (2) & Batabyal and Chakraborty (2015); Jasmin and Mallikarjuna (2014). \\
\hline Nickel (1) & Ramesh et al. (2010). \\
\hline Free chlorine (1) & Scheili et al. (2015). \\
\hline Barium (1) & Gharibi et al. (2012). \\
\hline Cyanide (1) & Bordalo and Savva-Bordalo (2007). \\
\hline Ryznar Index (1) & Abtahi et al. (2015). \\
\hline Colour (1) & Bordalo and Savva-Bordalo (2007). \\
\hline Salmonella (1) & Ramesh et al. (2010). \\
\hline Trihalomethanes (1) & Scheili et al. (2015). \\
\hline Haloacetic acid (1) & Scheili et al. (2015). \\
\hline Ultraviolet absorption (1) & Scheili et al. (2015). \\
\hline Heterotrophic coliforms (1) & Scheili et al. (2015). \\
\hline
\end{tabular}

The parameters most used to assess water quality were $\mathrm{pH}$, nitrate, turbidity, chloride and sulfate, cited in 10 of the 16 articles selected in this study (62,5\% of the total). The inorganic contaminant of greatest concern in groundwater is the nitrate ion, $\mathrm{NO}_{3}{ }^{-}$, which normally occurs in aquifers in rural and suburban areas. Nitrate in groundwater comes mainly from four sources: application of nitrogen fertilizers, animal manure in plantations; soil cultivation; human sewage deposited in septic systems; and atmospheric deposition (Baird and Cann, 2011). 
A recent concern deals with the increase in nitrate ion levels in drinking water, particularly in well water in rural localities, the main source of this nitrate being leaching from cultivated land into rivers and water flows. Excess nitrate ion in drinking water is worrying because it causes blue baby syndrome in newborns; in adults, it may be responsible for causing stomach cancer and increase the likelihood of breast cancer in women (Baird and Cann, 2011).

Chloride in drinking water comes from natural sources, sewers, industries, effluents, urban runoff containing defrost salt, and saline intrusion. High concentrations of chloride increase the metal corrosion rates in the distribution system, depending on the alkalinity of the water, and give a salty taste to water. The taste limits for the chloride anion depend on the associated cation and are in the range of $200-300 \mathrm{mg} \mathrm{L}^{-1}$ for sodium, potassium and calcium chloride. Excess concentrations of $250 \mathrm{mg} \mathrm{L}^{-1}$ are more likely to be detected by taste, but some consumers may get used to low levels of chloride-induced flavor. No health-based guideline proposes a concentration value for chloride in drinking water (WHO, 2017).

The presence of sulfate in drinking water can cause a noticeable taste, and very high levels can cause a laxative effect in unaccustomed consumers. Sulfates occur naturally in various minerals and are used commercially, mainly in the chemical industry. They are discharged into water in industrial waste and by atmospheric deposition; however, the highest levels generally occur in groundwater and are from natural sources. In general, the average daily intake of drinking water, air and food sulfate is approximately $500 \mathrm{mg}$, with food being the main source. However, in areas with drinking water supplies containing high levels of sulfate, drinking water can be the main intake source. No health-based guidelines are proposed for sulfate. However, due to gastrointestinal effects resulting from drinking water containing a high sulfate content, it is recommended that health authorities are notified of drinking water sources containing sulfate concentrations above $500 \mathrm{mg} \mathrm{L}^{-1}$ (WHO, 2017).

$\mathrm{pH}$ is a measure of the concentration of $\mathrm{H}^{+}$ions in water. The balance of hydrogen and hydroxide ions $\left(\mathrm{OH}^{-}\right)$determines how acidic or basic water is. In chemically pure water, the $\mathrm{H}^{+}$ions are in equilibrium with the $\mathrm{OH}^{-}$ions and their $\mathrm{pH}$ is neutral, that is, equal to 7 . The main factors that determine the $\mathrm{pH}$ of water are dissolved carbon dioxide $\left(\mathrm{CO}_{2}\right)$ and alkalinity. $\mathrm{pH}$ has a direct relationship with the quality of water for human consumption. Water with a high carbon dioxide content, reduced total alkalinity and low $\mathrm{pH}$ is considered aggressive. Aggressive waters are those that tend to dissolve calcium carbonate. Water with a low $\mathrm{pH}$ promotes corrosion of metal pipes and fittings, namely copper, lead and zinc, which can cause problems such as a metallic or sour taste (ERSAR, 2008; WHO, 2011).

A pH greater than 8.5 may indicate that the water is hard. It does not pose a health risk, but it can cause esthetic problems, such as incrustations in pipes and equipment, causing a decrease in the inside diameter; alkaline flavor; difficulty in obtaining foam; and formation of insoluble precipitates on clothes. Turbidity has a potential health effect: it is often associated with the presence of microorganisms originating in surface runoff from soil (WHO, 2017).

The presence of microbiological agents (Escherichia coli, coliforms), can generate acute and generalized effects on the health of consumers without changing the flavor, odor or color of water. The greatest public health risk of microbes in water is associated with drinking water that is contaminated with human and animal excrement, although other sources and routes of exposure may also be significant. Outbreaks transmitted by water have been associated with inadequate water treatment and unsatisfactory management of drinking water distribution.

There are few chemical substances in the water causing health problems, except for massive water contamination, such as in environmental accidents, and it is commonly impossible to consume the water due to its taste, odor or general appearance. Therefore, variations in the concentration of chemical elements in the water, even if for short periods they present values above those allowed does not necessarily mean that it is not fit for consumption.

Rev. Ambient. Água vol. 16 n. 2, e2630 - Taubaté 2021 
The proportion by which the permitted values can be exceeded and the period for which this situation can be prolonged without prejudice to health will depend on each substance or element considered.

The problems related to the elements or chemical substances present in water for human consumption are mainly due to the negative effects to health after prolonged periods of exposure to organic contaminants and toxic heavy metals. The radioactive aspects depend on naturally occurring radioactive isotopes that start from the uranium decay series, such as lead $210 \mathrm{mg} \mathrm{L}^{-}$ ${ }^{1}$ and uranium $238 \mathrm{mg} \mathrm{L}^{-1}$ and $234 \mathrm{mg} \mathrm{L}^{-1}$. The presence of radionuclides, even in normal circumstances, must be considered.

As for the acceptability aspects of drinking water, the population bases them on properties such as taste, color, odor, appearance, turbidity and other parameters perceptible to its taste. Esthetically unacceptable water will decrease consumer confidence, leading to complaints and, more importantly, to the use of water from less secure sources. Consumers have no means of judging the quality of their drinking water, but their attitude towards drinking water supplies and suppliers will be largely affected by the aspects of quality that they are able to perceive with their own senses. Consumers consider unacceptable water that is not colorless or which has an unpleasant taste or smell, even though these characteristics may not have direct health impacts.

It is important to consider whether existing water treatment and distribution practices can affect the acceptability of drinking water, as well as managing changes and operations to minimize the risk of acceptability problems. For example, chloramination that is not properly managed can lead to the formation of trichloramines, which can cause unacceptable taste and odor. Other problems can be indirect, such as internal deposits in pipes when the flow in distribution systems is disturbed or altered.

The water quality parameters used to assess the quality of drinking water were classified into microbiological, chemical, radioactive and acceptance aspects, as described in the Guidelines for Drinking-water Quality (WHO, 2017). The parameters not included in these categories were classified in "others" (Table 5).

In Brazil, according to the Consolidation Ordinance $n^{\circ} 5 / 2017$ of the Ministry of Health (Brasil, 2017), some physical, chemical and bacteriological parameters must be followed to ensure their potability, considering their respective regulatory standards listed in Annex XX (Table 6), which deals with the control and surveillance of water quality for human consumption. All water intended for human consumption from an individual alternative water supply solution, regardless of how the population accesses it, is subject to water quality monitoring.

\subsection{SQ1 - Where the surveys were published?}

The articles were categorized in the four databases used in this systematic review. Table 7 shows the number of articles published by the database, highlighting ScienceDirect with 10 articles. No articles were published in the Scielo database. In a general way, little is found in the literature about comparative analysis related to the development, comparison and application of different WQI's; currently, there is great concern about controlling the quality of the water we consume. A series of indices are being developed and adapted for consumption.

The database that stood out most for the publication of studies on WQI within the selection criteria was ScienceDirect. It was observed that the impact of human activity was severe in most parameters. The maximum permitted values have exceeded the tolerable limits in some situations. Yet the main cause of deterioration in water quality is the lack of adequate sanitation, unprotected river areas and high anthropogenic activity. Water is essential to sustain life; there must be a satisfactory supply (adequate, safe and accessible) and it must be available to everyone. Improving access to contaminant-free drinking water can result in tangible health benefits. Every effort should be made to obtain drinking water that is as safe as possible. 
Table 5. Water quality parameter classification (WHO, 2017).

\begin{tabular}{|c|c|c|c|c|}
\hline Microbiological & Chemicals & Radioactive & Acceptability & Others \\
\hline $\begin{array}{c}\text { Total coliforms } \\
\text { Escherichia coli } \\
\text { Fecal coliforms } \\
\text { Fecal enterococci } \\
\text { Salmonella } \\
\text { Heterotrophic } \\
\text { coliforms }\end{array}$ & $\begin{array}{c}\text { Fluoride } \\
\text { Total hardness } \\
\text { Nitrate } \\
\text { Aluminum } \\
\text { Potassium } \\
\text { Chromium } \\
\text { Zinc } \\
\text { Copper } \\
\text { Nitrite } \\
\text { Cyanide } \\
\text { Ammonia } \\
\text { Cadmium } \\
\text { Arsenic } \\
\text { Barium } \\
\text { Nickel } \\
\text { Mercury } \\
\text { Chloride } \\
\text { Manganese } \\
\text { pH } \\
\text { Sodium } \\
\text { Sulfate } \\
\text { Iron } \\
\text { Lead } \\
\text { Bicarbonate } \\
\text { Total dissolved } \\
\text { solids }\end{array}$ & Lead & $\begin{array}{c}\mathrm{pH} \\
\text { Chloride } \\
\text { Sulfate } \\
\text { Chlorine } \\
\text { Sodium } \\
\text { Total dissolved } \\
\text { solids } \\
\text { Iron } \\
\text { Manganese } \\
\text { Turbidity } \\
\text { Total hardness } \\
\text { Zinc } \\
\text { Dissolved oxygen } \\
\text { Aluminium } \\
\text { Ammonia } \\
\text { Colour } \\
\text { Copper }\end{array}$ & $\begin{array}{c}\text { Temperature } \\
\text { Calcium } \\
\text { Magnesium } \\
\text { Phosphate } \\
\text { Total organic carbon } \\
\text { Electric conductivity } \\
\text { Total alkalinity } \\
\text { Biochemical oxygen } \\
\text { demand }\end{array}$ \\
\hline
\end{tabular}

Table 6. Water quality parameters in Brazil, following the Consolidation Ordinance $n^{\circ}$ 5/2017 of the Ministry of Health (Brasil, 2017).

\begin{tabular}{lc}
\hline Potability parameter & Maximum value allowed \\
\hline Free Residual Chlorine & $0,2-2,0 \mathrm{mg} \mathrm{L}^{-1}$ \\
pH & $6,0-9,5$ \\
Apparent Color & $15 \mathrm{CU}$ \\
Fluoride & $1,5 \mathrm{mg} \mathrm{L}^{-1}$ \\
Turbidity & $5 \mathrm{NTU}$ \\
Total Coliforms & Absence in $100 \mathrm{~mL}$ \\
Escherichia coli & Absence in $100 \mathrm{~mL}$ \\
Heterotrophic Bacteria & $500 \mathrm{UFC} \mathrm{\textrm {mL } ^ { - 1 }}$ \\
\hline
\end{tabular}

Table 7. Classification of results.

\begin{tabular}{ll}
\hline Database & Articles \\
\hline PubMed & Paca et al. (2019); Batabyal and Chakraborty (2015); Cooray et al. (2019). \\
\hline Web of Science & Avvannavar and Shrihari (2008); Jasmin and Mallikarjuna (2014); Scheili et al. (2015). \\
Science Direct & $\begin{array}{l}\text { Masocha } \text { et al. (2019); Mukate } \text { et al. (2019); Ponsadailakshmi } \text { et al. (2018); Barakat } \text { et al. } \\
\text { (2018); Mohebbi } \text { et al. (2013); Hurley } \text { et al. (2012); Gharibi } \text { et al. (2012); Abtahi } \text { et al. } \\
\end{array}$ \\
& (2015); Bordalo and Savva-Bordalo (2007); Ramesh et al. (2010). \\
\hline
\end{tabular}


Safe drinking water, as defined by authorities that determine its parameters, does not represent a significant health risk during the entire consumption life, including in those with sensitivities that can occur at different stages of life. Those most at risk for waterborne diseases are children and elderly people, especially when living in unsanitary conditions. Those who are generally at risk for waterborne illnesses may need to take additional measures to protect themselves from exposure to waterborne pathogens, such as boiling drinking water. Safe drinking water is required for all usual household purposes, including drinking, food preparation and personal hygiene. Therefore, the development of indices to assess the quality of drinking water is essential for each human being to have access to the quality of the water they are consuming.

\section{CONCLUSION}

This systematic review presented the search for WQI's for human consumption. In addition, it presented different models of variables associated with the quality of drinking water, in order to obtain a better result for water quality. However, none of the reviewed articles documented how a historical database could effectively improve this goal with the support of new technologies. The bibliographic references selected in this systematic review allow us to observe that, although the frequency of studies related to WQI's for drinking has increased in recent years, the number of studies is still insufficient to obtain effective scientific evidence. One of the gaps found during this research corresponds to evaluation of the parameters analyzed and their separation between microbiological, radioactive, chemical, acceptability and others, highlighting that the basic and essential requirements to guarantee the safety of drinking water are based on the health established by competent health system authorities and adequate surveillance systems.

We suggest that future research seek to propose regionalized WQI's for consumption, in order to consider local aspects in the evaluation process and to determine intervention priorities for health surveillance agencies. In addition, the development of computerized platforms for centralizing information on these WQI's, accessible to the public in real time, is essential for the effective implementation of programs for monitoring the quality of drinking water.

\section{REFERENCES}

ABTAHI, M.; GOLCHINPOUR, N.; YAGHMAEIAN, K.; RAFIEE, M.; JAHANGIRI-RAD, M.; KEYANI, A.; SAEEDI, R. A modified drinking water quality index (DWQI) for assessing drinking source water quality in rural communities of Khuzestan Province, Iran Ecological Indicators, n. 53, p. 283-291, 2015. https://doi.org/10.1016/j.ecolind.2015.02.009

AKKOYUNLU A.; AKINER, M. E. Pollution evaluation in streams using water quality indices: a case study from Turkey's Sapanca Lake Basin. Ecological Indicator, n. 18, p. 501-511, 2012.

AVVANNAVAR, S. M.; SHRIHARI, S. Evaluation of water quality index for drinking purposes for river Netravathi, Mangalore, South India. Environmental monitoring and assessment, v. 143, n. 1-3, p. 279-290, 2008.

BAIRD, C.; CANN, M. Química ambiental. 4. ed. Porto Alegre: Bookman, 2011.

BATABYAL, A. K.; CHAKRABORTY, S. Hydrogeochemistry and Water Quality Index in the Assessment of Groundwater Quality for Drinking Uses. Water, v. 87, n. 7, p. 607617, 2015. https://doi.org/10.2175/106143015X14212658613956 
BARAKAT, A.; MEDDAH, R.; AFDALI, M.; TOUHAMI, F. Physicochemical and microbial assessment of spring water quality for drinking supply in Piedmont of Béni-Mellal Atlas (Morocco). Physics and Chemistry of the Earth, Parts A/B/C, v. 104, p. 39-46, 2018. https://doi.org/10.1016/j.pce.2018.01.006

BORDALO, A. A.; SAVVA-BORDALO, J. The quest for safe drinking water: an example from Guinea-Bissau (West Africa). Water Research, n. 41, p. 2978-2986, 2007.

BRASIL. Ministério da Saúde. Portaria de Consolidação no 5, de 28 de setembro de 2017. Ministério da Saúde. Consolidação das normas sobre as ações e os serviços de saúde do Sistema Único de Saúde. Diário Oficial [da] União: seção 1, Brasília, DF, 03 out. 2017.

BROWN, R. M.; MCCLELLAND, N. I.; DEININGER, R. A.; TOZER, R. G. A water quality index - do we dare? Water Sewage Works, v. 117, n. 10, p. 339-343, 1970.

CETESB. Qualidade das águas interiores no Estado de São Paulo 2018. São Paulo, 2019. Available in: https://cetesb.sp.gov.br/aguas-interiores/publicacoes-e-relatorios Access: 23 jul. 2020.

COORAY, T.; WEI, Y.; ZHANG, J.; ZHENG, L.; ZHONG, H.; WERAGODA, S. K.; WEERASOORIYA, R. Drinking-Water Supply for CKDu Affected Areas of Sri Lanka, Using Nanofiltration Membrane Technology: From Laboratory to Practice. Water, v. 11, n. 12 , p. 2512, 2019. https://doi.org/10.3390/w11122512

CONAMA (Brasil). Resolução $\mathrm{n}^{\circ} 357$ de 17 de março de 2005. Dispõe sobre a classificação dos corpos de água e diretrizes ambientais para o seu enquadramento, bem como estabelece as condições e padrões de lançamento de efluentes, e dá outras providências. Diário Oficial [da] União: seção 1, Brasília, DF, n. 053, p. 58-63, 18 mar. 2005.

COOPER, I. D. What is a "mapping study?". Journal of Medical Library Association, v. 104, p. 76-78, 2016. https://doi.org/10.3163/1536-5050.104.1.013

CUDE, C. Oregon water quality index: A tool for evaluating water quality management effectiveness. Journal of the American Water Resources Association, n. 37, p. 125$137,2001$.

ERSAR. Recomendação no. 2/2008. Correcção da agressividade da água destinada ao consumo humano em pequenos aglomerados. Lisboa, 2008.

FINOTTI, A. R.; FINKLER, R.; SUSIN, N.; SCHNEIDER, V. E. Use of water quality index as a tool for urban. International Journal of Sustainable Development and Planning, v. 10, n. 6, p. 781-794, 2015.

FUNDAÇÃO NACIONAL DE SAÚDE (Brasil). Manual prático de análise de água. 3. ed. Brasília, 2009.

GHARIBI, H.; MAHVI, A. H.; NABIZADEH, R.; ARABALIBEIK, H.; YUNESIAN, M.; SOWLAT, M. H. A novel approach in water quality assessment based on fuzzy logic. Journal of Environmental Management, n. 112, p. 87-95, 2012. https://doi.org/10.1016/j.jenvman.2012.07.007

HURLEY, T.; SADIQ, R.; MAZUMDER, A. Adaptation and evaluation of the Canadian Council of Ministers of the Environment Water Quality Index (CCME WQI) for use as an effective tool to characterize drinking source water quality. Water Research, n. 46, p. 3544-3552, 2012. 
JASMIN, I.; MALLIKARJUNA, P. Physicochemical quality evaluation of groundwater and development of drinking water quality index for Araniar River Basin, Tamil Nadu, India. Environmental monitoring and assessment, v. 186, n. 2, p. 935-948, 2014. https://dx.doi.org/10.1007/s10661-013-3425-7

KACHROUD, M.; TROLARD, F.; KEFI, M.; JEBARI, S.; BOURRIÉ, G. Water Quality Indices: Challenges and Application. Water, n. 11, p. 1-26, 2019.

KESHAV, S. How to read a paper. ACM SIGCOMM Computer Communication Review. v. 37, n. 83, 2007. https://doi.org/10.1145/1273445.1273458

KITCHENHAM, B.; CHARTERS, S. Guidelines for performing Systematic Literature Reviews in Software Engineering. EBSE 2007-001. Durham: University of Durham, 2007.

KLAMT, R. A.; LOBO, E. A.; COSTA, A. B.; DELEVATI, D. M. Evaluation of water resource preservation areas in the Hydrographical Basin of Andreas Stream, RS, Brazil, using environmental monitoring programs. Revista Ambiente \& Água, v. 14, n. 2, 2019.

MASOCHA, M.; DUBE, T.; DUBE, T. Integrating microbiological and physico-chemical parameters for enhanced spatial prediction of groundwater quality in Harare. Physics and Chemistry of the Earth, parts A/B/C, v. 112, p. 125-133, 2019. https://doi.org/10.1016/j.pce.2019.03.003

MOHEBBI; M. R.; SAEEDI, R.; MONTAZERI, A.; VAGHEFI, K. A.; LABBAFI, S.; OKTAIE, S.; ABTAHI, M.; MOHAGHEGHIAN, A. Assessment of water quality in groundwater resources of Iran using a modified drinking water quality index (DWQI). Ecological Indicators, n. 30, p. 28-34, 2013.

MORETTO, D. L.; PANTA, E.; COSTA, A. B.; LOBO, E. A. Calibration of Water Quality Index (WQI) based on Resolution $n^{\circ} 357 / 2005$ of the Environment National Council (CONAMA) Brazil. Acta Limnologica Brasiliensia, v. 24, n. 1, p. 29-42, 2012.

MUKATE, S.; WAGH, V.; PANASKAR, D.; JACOBS, J. A.; SAWANT, A. Development of new integrated water quality index (IWQI) model to evaluate the drinking suitability of $\begin{array}{llllll}\text { water. Ecological Indicators, } & \text { v. 101, p. 348-354, } 2019 .\end{array}$ https://doi.org/10.1016/j.ecolind.2019.01.034

PACA, J. M.; SANTOS, F. M.; PIRES, J. C. M.; LEITÃO, A. A.; BOAVENTURA, R. A. R. Quality assessment of water intended for human consumption from Kwanza, Dande and $\begin{array}{lllll}\text { Bengo rivers (Angola). Environmental Pollution, } & \text { v. 254, }\end{array}$ 2019. https://doi.org/10.1016/j.envpol.2019.113037

PETERSEN, K.; FELDT, R.; MUJTABA, S.; MATTSSON, M. Systematic Mapping Studies in Software Engineering. IN: INTERNATIONAL CONFERENCE ON EVALUATION AND ASSESSMENT IN SOFTWARE ENGINEERING, EASE'08, 12., 26-27 jun. 2008, Bari. Proceedings[...] Swindon: BCS Learning \& Development, 2008. p. 68-77.

PONSADAILAKSHMI, S.; GANAPATHY SANKARI, S.; MYTHILI PRASANNA, S.; MADHURAMBAL, G. Evaluation of water quality suitability for drinking using drinking water quality index in Nagapattinam district, Tamil Nadu in Southern India. Groundwater for Sustainable Development, v. 6, p. 43-49, 2018. https://doi.org/10.1016/j.gsd.2017.10.005 
POSSELT, E. L.; COSTA, A. B.; LOBO, E. A. Software IQAData 2015. BR n. PI 512015000890-0, 2015.

RAMESH, S.; SUKUMARAN, N.; MURUGESAN, A.G.; RAJAN, M. P. An innovative approach of drinking water quality index - a case study from southern Tamil Nadu, India. $\begin{array}{llllll}\text { Ecological Indicators, } & \text { n. } & 10, & \text { p. } & 857-868, & \end{array}$ https://doi.org/10.1016/j.ecolind.2010.01.007

SAMPAIO, R. F.; MANCINI, M. C. Estudos de revisão sistemática: um guia para síntese criteriosa da evidência científica. Revista Brasileira de Fisioterapia, v. 11, n. 1, p. 8389, 2007. http://dx.doi.org/10.1590/S1413-35552007000100013

SCHEILI, A.; RODRIGUEZ, M. J.; SADIQ, R. Development, application, and sensitivity analysis of a water quality index for drinking water management in small systems. Environmental Monitoring \& Assessment, v. 187, n. 11, p. 1-9, 2015. https://doi.org/10.1007/s10661-015-4908-5

TYAGI, S.; SHARMA, B.; SINGH, P.; DOBHAL, R. Water quality assessment in terms of water quality index, American Journal of Water Resources, n. 1, p. 34-38, 2013.

WORLD HEALTH ORGANIZATION. Guidelines for drinking-water quality, 4th edition, incorporating the 1st addendum (chapters). Geneva, 2017.

WORLD HEALTH ORGANIZATION. Guidelines for Drinking-Water Quality: Incorporating First Addendum, 3. ed., v. 1, recommendations. Geneva, 2006.

WORLD HEALTH ORGANIZATION. Guidelines for Drinking-Water Quality. 4. ed. Geneve, 2011.

YOGENDRA, K.; PUTTAIAH, E.T. Determination of water quality index and suitability of an urban waterbody in Shimoga Town, Karnataka. IN: WORLD LAKE CONFERENCE, 12., 28 oct - 02 nov. 2007, Jaipur. Proceedings[...] Jaipur, 2008, p. 342-346. 